\title{
A PRACTICAL GUIDE ON USING ICT IN ENGLISH LANGUAGE EDUCATION
}

\author{
Xiaojun WANG*, Palacký University Olomouc, Czech Republic
}

Přijato: 11. 9. 2017 / Akceptováno: 11. 9.2017

Typ článku: Recenze

DOI: $10.5507 /$ jtie.2017.019

Book review: Motteram G.( Ed). Innovations in learning technologies for English language teaching. British Council. 2013, 197 p., ISBN 978-0-86355-713-2.

The advance of computer technology enables us to get access to a variety of Information and Communication Tools (ICT) increasingly being used in educational fields. Internet, web2.0, mobile phones and tablets, just to name a few, have a great impact on the process of education. It can expand equal access to learning, facilitate personalized learning, provide immediate feedback and assessment, enable anytime, anywhere learning, ensure productive use of time spent in classrooms, build new communities of learners, support situated learning, enhance seamless learning, bridge formal and informal learning, minimize educational disruption in conflict and disaster areas, assist learners with disabilities and improve communication and administration (UNESCO, 2013). Many studies have also shown that digital technologies can improve the outcome of education and enhance students' engagement in study (Barak \& Watted \& Haick, 2016; Wang \& Teng \& Chen, 2015; Barrs, 2012; Blattner \& Fiori, 2009).

It is true that computer technology has been gradually integrated into classroom teaching in the developing as well as the developed countries. However, for a long time, it has been assumed that classroom applications of computer technologies are limited to PowerPoint, internet, slide projectors and the like. The book, "Innovations in Learning Technologies for English Language Teaching", edited by Gary Motteram who is an expert in the field of computer supported language teaching and learning, provides an extensive and more detailed view of technological classroom application. It emphasizes on how to use ICT in teaching English as a foreign language. Throughout the book are examples of real life teaching experiences from all over the world, which are valuable to English teachers teaching different levels of students in schools or teaching a particular student with a special purpose, such as business English or English for academic purposes. It is worthy to point out that this book is also concerned with how technology can be used in assessing English Language Teaching (ELT), offering an effective and efficient way for the assessment necessary in the process of English Language Teaching.

This book is an edited work containing seven chapters preceded by an introduction about the purpose of this book and the main content of each chapter. In the introduction, Gary summarizes nearly all the journals related to Computer Assisted Language Learning (CALL), which constitutes a useful resource for researchers engaging in this field. In

*Autor pro korespondenci: $\underline{\text { d005007@ 163.com }}$ 
addition, in this part, Gary used a table to illustrate all the technologies used in each case study, providing teachers with the convenience of understanding what kind of technology can be used in a particular teaching practice. Each chapter subsequent to the introduction in this book can be regarded as an individual and completed thesis respectively written by a prestigious professional with rich experiences and a profound insight in using ICT to promote language teaching and learning. Although this book has seven chapters, it can be concluded that this book mainly talks about three things: the use of computer technology in teaching English for general use, how to use ICT to support English language teaching for special use and how to use digital technology in assessment of ELT. Learners studying English for general use include young learners ( students at primary schools and secondary schools) and adult learners. Individual chapters explain how teachers teaching a particular group of students can find a variety of ways to use ICT in teaching practices. Teachers teaching English for students with special uses can also easily find methods in the corresponding chapter. This is also the case for teachers who are worried about how to use ICT in assessment.

\section{This book is unique in three respects:}

First, this book is very practical. It is written especially for English language teachers. There are a number of real cases studies about how to use computer technology in teaching English for different groups of students with different purposes. It combines theory with examples relevant to the topic in question. The cases are told in detailed ways but without any surplus narration so that they are easy to be understood. English language teachers can learn from these examples and apply them to their own teaching practice. Some ICT are common in our life, but we have little knowledge about how they are enacted in education, especially in language teaching. For example, Skype is a common communicative tool easy to use and is widely used in our work and our everyday life. However, very few people think it can be used as a pedagogical tool in educational settings. After reading this book, we are informed that Skype can be used to motivate students' learning of English at secondary school, and it also can be used by English language teachers in teaching English special purpose courses. As shown in this book, Skype can be used as an educational tool to teach English for politicians as well as businessmen. These examples offer a new insight into the infusion of ICT in English language learning. Apart from this, this book also discusses those technologies unfamiliar to us before we read this book, which extends our vision of the interface between computer technology and English language teaching. Additionally, innovative approaches are offered to teachers who desire effective ways of assessment of English language teaching.

Second, the perspective of this book is overview. It provides readers with a range of contexts of the uses of technologies in language teaching, including primary education, secondary education, adult education, lessons for special purposes, and language teaching assessment. Case studies shown in the book are from all over the world. The use of ICT in teaching English language is explained from the perspective of formal teaching to informal teaching and from language teaching to language teaching assessment. In addition, the expository of how to use ICT in English language teaching is conducted from four English aspects: speaking skill, writing skill, listening skill and reading skill.

Third, the structure of this book is well-organized. In a broad sense, the chapters in this book are arranged from early learners to adult learners, from English language 
teaching for general use to English language teaching for special use. Each individual chapter is for particular English teachers teaching in particular settings so that it is easy for individual English language teachers to find the knowledge they need by viewing the table of contents in this book. The content of each chapter is organized according to the same model composed of theory and cases studies.

On the whole, this book is a rare work available with respect to using computer technologies in English language teaching. The real experiences in different language teaching settings shown in this book are valuable references for current and future English language teachers. The prominent distinction between this book and other teaching resource books lies in the fact that it provides readers with a real and new insight into how teachers actually integrate the technologies into class teaching to support the learning outcomes of the class. Various real examples of teaching experiences illustrating a variety of ways to use ICT in the process of English language education are presented in every chapter throughout the book. Although this book is primarily useful for English language teachers, it is still of value to other language teachers as language teaching is similar.

\section{References}

Barak, M., Watted, A. \& Haick, H. (2016). Motivation to learn in massive open online courses: Examining aspects of language and social engagement. Computer \& Education, 94, 49-60.

Wang, B. T., Teng, C. W. \& Chen, H. T. (2015). Using iPad to Facilitate English Vocabulary Learning. Int. Journal of Information and Education Technology, Vol. 5, No. 2,100-104.

Barrs, K. (2012). Fostering computer-mediated L2 interaction beyond the classroom. Language Learning \& Technology, 16(1), 10-25.

Blattner, G., \& Fiori, M. (2009). Facebook in the language classroom: Promises and possibilities. Instructional Technology and Distance Learning (ITDL), 6(1), 17-28. UNESCO. (2013). UNESCO Policy Guidelines for Mobile Learning. Paris: UNESCO. Motteram , G.( Ed).(2013). Innovations in learning technologies for English language teaching. British Council. 